The Midwife and Society 
Also by the same authors and from Macmillan

THE SOCIAL MEANING OF MIDWIFERY 


\section{The Midwife and Society}

\section{Perspectives, Policies and Practice}

Anthea Symonds

Lecturer in Social Policy

University of Wales, Swansea

AND

Sheila C. Hunt

Professor of Midwifery

University of Central England and

Birmingham Women's Health Care NHS Trust

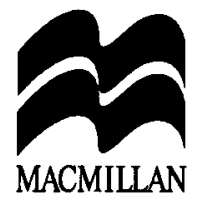


C Anthea Symonds and Sheila C. Hunt 1996

Foreword @ Sarah Roch 1996

All rights reserved. No reproduction, copy or transmission of this publication may be made without written permission.

No paragraph of this publication may be reproduced, copied or transmitted save with written permission or in accordance with the provisions of the Copyright, Designs and Patents Act 1988, or under the terms of any licence permitting limited copying issued by the Copyright Licensing Agency, 90 Tottenham Court Road, London W1P 9HE.

Any person who does any unauthorised act in relation to this publication may be liable to criminal prosecution and civil claims for damages.

First published 1996 by MACMILLAN PRESS LTD

Houndmills, Basingstoke, Hampshire RG21 6XS and London

Companies and representatives

throughout the world

ISBN 978-0-333-63038-9

ISBN 978-1-349-13654-4 (eBook)

DOI 10.1007/978-1-349-13654-4

A catalogue record for this book is available from the British Library.

This book is printed on paper suitable for recycling and made from fully managed and sustained forest sources

$\begin{array}{rrrrrrrrrr}10 & 9 & 8 & 7 & 6 & 5 & 4 & 3 & 2 & 1 \\ 05 & 04 & 03 & 02 & 01 & 00 & 99 & 98 & 97 & 96\end{array}$


Dedicated to those midwives who are curious about the world in which they live and are prepared to ask why

and

For my father, Joseph Eric Martin, who had a way with words

(Sheila C. Hunt) 


\section{Contents}

List of figures $\quad$ xi

List of tables $\quad$ xii

Foreword by Sarah Roch xiii

Acknowledgements xiv

List of abbreviations $\quad \mathbf{x v}$

Introduction $\quad$ xvii

PART I SOCIOLOGICAL THEORY APPLIED TO MIDWIFERY 1

1 What is sociology? 3

Understanding how society works 4

Where do ideas and beliefs come from? $\quad 6$

$\begin{array}{ll}\text { Sociology and theory } & 7\end{array}$

$\begin{array}{ll}\text { Sociological theories of power } & 8\end{array}$

$\begin{array}{lr}\text { Marxism(s) } & 8\end{array}$

$\begin{array}{ll}\text { Functionalism and power } & 10\end{array}$

$\begin{array}{ll}\text { Weber, belief systems and power } & 11\end{array}$

Labelling and roles $\quad 13$

Feminism(s) 14

Foucault, post-structuralism and discourses of power 16

$\begin{array}{ll}\text { Midwifery and sociology } & 17\end{array}$

Case study $1.1 \quad 19$

Questions and discussion points $\quad 19$

$\begin{array}{ll}\text { Key points } & 20\end{array}$

2 Social divisions and patterns of inequality 22

$\begin{array}{ll}\text { Social Class } & 23\end{array}$

'Race' and ethnicity $\quad 29$

Defining sex and gender $\quad 36$

Gender and patriarchal power $\quad 38$ 
viii - Contents

$\begin{array}{lr}\text { Age } & 40\end{array}$

Poverty $\quad 43$

Case study 2.1 $\quad 56$

Case study $2.2 \quad 56$

Questions and discussion points $\quad 57$

Key points $\quad 58$

3 Sociological perspectives on 'the family' and community $\quad 59$

When was 'the family'? $\quad 59$

Families today $\quad 60$

'Ethnic minority' families $\quad 65$

$\begin{array}{ll}\text { The family as a social structure } & 67\end{array}$

$\begin{array}{ll}\text { The family as a social process } & 68\end{array}$

Power structures within the family $\quad 70$

The family as ideology $\quad 72$

Sociology and community $\quad 76$

The family, community and midwifery care $\quad 79$

$\begin{array}{ll}\text { Case study } 3.1 & 79\end{array}$

Questions and discussion points $\quad 80$

$\begin{array}{ll}\text { Case study } 3.2 & 80\end{array}$

$\begin{array}{ll}\text { Questions and discussion points } & 81\end{array}$

$\begin{array}{ll}\text { Key points } & 81\end{array}$

4 Social aspects of pregnancy and childbirth 83

$\begin{array}{ll}\text { The private event } & 83\end{array}$

$\begin{array}{ll}\text { The public event } & 85\end{array}$

The scan - 'seeing' the baby $\quad 86$

Smoking, pregnancy and social class $\quad 88$

Hospitalisation and the male 'take over' 90

$\begin{array}{ll}\text { The medicalisation of birth } & 93\end{array}$

Birth as a social experience $\quad 96$

Case study 4.1 98

Questions and discussion points $\quad 99$

$\begin{array}{ll}\text { Key points } & 99\end{array}$

5 Social aspects of motherhood 101

Motherhood as a social and historical construct 102

A social understanding of post-natal depression 113

'Good' and 'bad' mothers and bonding $\quad 116$

$\begin{array}{ll}\text { Motherhood and sexuality } & 118\end{array}$

$\begin{array}{ll}\text { The social meaning of fatherhood } & 119\end{array}$

Case study $\quad 122$

Questions and discussion points $\quad 123$

$\begin{array}{ll}\text { Key points } & 123\end{array}$ 


\section{PART II SOCIAL POLICY, WOMEN AND} PROFESSIONALISATION

6 Social policy, family and community 127

$\begin{array}{ll}\text { The family in social policy } & 128\end{array}$

Policies on marriage and divorce $\quad 130$

The end of the male bread-winner model? 133

From family allowance to family credit 136

Child support and fathers $\quad 141$

Child care and Child protection $\quad 145$

Adoption and fostering $\quad 146$

Community care $\quad 148$

Questions and discussion points 151

Key points 152

$7 \quad$ Women and social policy $\quad 154$

Women and citizenship $\quad 155$

Policies on contraception and abortion $\quad 156$

$\begin{array}{ll}\text { Maternity benefits } & 160\end{array}$

Child care $\quad 162$

Equal opportunities and sex discrimination $\quad 165$

$\begin{array}{ll}\text { Women and benefits } & 167\end{array}$

Housing and homelessness $\quad 171$

Mothers in employment $\quad 178$

$\begin{array}{ll}\text { Case study } & 179\end{array}$

Questions and discussion points $\quad 179$

$\begin{array}{ll}\text { Key points } & 180\end{array}$

8 Power, professionalisation and midwifery 182

What is a profession? 182

The semi-professions and women 184

Strategies of professionalisation $\quad 185$

The professionalisation of medicine $\quad 186$

$\begin{array}{ll}\text { Medicine and social divisions } & 189\end{array}$

Professionalisation of gynaecology and obstetrics $\quad 191$

Theory and practice 194

$\begin{array}{ll}\text { What is skill? } & 197\end{array}$

The professionalisation of midwifery 199

Professional regulation and covert control 204

Midwifery education 204

What is a midwife? Public images and reality 206

Pressure groups and other influences 207

Changing Childbirth: some implications of social policy 208

New power for old? $\quad 210$ 
$\mathrm{x}$. Contents

Questions and discussion points

Key points

213

Conclusions

214

References

215

Index

230 


\section{List of figures}

2.1 Average gross weekly earnings, by gender, April 1994

2.2 Older people, by sex, age group and family situation, 1991

2.3 Percentage of people whose income is below selected fractions of average income, before hausing costs, 1961-92

2.4 The growth of dependency: number of recipients of means-tested benefits, 1979-94

2.5 People in poverty, below 40 per cent of average income, before housing costs, 1961-89

2.6 Occupational class and mortality in babies and adults, early 1980 s

2.7 Low birthweight, by father's social class, 1992

3.1 Lone-parent families, 1991

3.2 Average household size, by ethnic group of head of household, 1991

3.3 Lone mothers as percentage of all mothers, by ethnic group, 1989-91

3.4 Women with dependent children, working full-time and part-time, 1979-81 and 1990-2

3.5 The prevalence of domestic violence in a woman's lifetime, by type of violence, 1994

6.1 Key facts on parents, 1992

6.2 Numbers of lone parents on Income Support, all ages, 1979 and 1994/5

6.3 Children in care, admissions to care and children removed to a place of safety, 1981-91

7.1 Home ownership, by household type, 1984 and 1991 


\section{List of tables}

2.1 Registrar-General's classification of social class 24

2.2 Ethnic group composition of the population, 1992

2.3 Population, by age and ethnic group, 1989-91 33

2.4 Employment, by broad occupation, ethnic origin and sex,
Spring 1989-91

2.5 Live births, by age of mother, 1941-91 43

2.6 Rates of admission to hospitals per 100000 population, by sex and diagnostic group, 1986

3.1 People in households, by type of household and family in which they live, 1961-92

3.2 Divorce, by sex and age, per 1000 married population, 1961-91

3.3 Conceptions, by marital status and outcome, 1971-91 63

3.4 Division of household tasks, 1995

5.1 Non-marital births, adoptions and abortions , 1959-84 104

6.1 Proportion of net family income with and without Child Benefit contributed by women in couples, 1991

6.2 Spending on and receipt of social security benefits, 1990-1

6.3 Social Fund payments, $1990 \quad 140$

7.1 Childcare arrangements for women employees with
youngest child under 5, 1990

7.2 Social security claimants, by sex, $1990 \quad 168$

7.3 Employment rates of lone mothers, actual and preferred, 1991

7.4 Total weekly income, single mother and one child, from Income Support and Child Benefit, 1995

7.5 Supplementary Benefit recipients, by tenure, 1972 and $1984 \quad 174$

7.6 Households living in temporary accommodation, 1982-92 178 


\section{Foreword}

Midwives are generally sceptical of politics, even with a small ' $\mathrm{p}$ ', and have only slowly begun to realise that political naivety is both dangerous and diminishing. Anthea Symonds' and Sheila Hunt's excellent text will surely demonstrate to them that understanding the sociological context in which they practise midwifery is also a prerequisite for attaining that proper political perspective, without which the art and science of midwifery will not prosper or develop to meet the ever-changing needs of the public we all serve.

This book provides a thought-provoking look at our professional practice and identifies its many-faceted background, particularly in relation to power and its proper use, roles, gender and health inequalities.

Not all the observations are comfortable for us and the book challenges us to look anew at our stereotypes and unresearched practices. My hope is that all midwives will read this book and reflect upon their practice in the light of the empowerment it provides. In his Essay on Human Understanding the philosopher John Locke (1632-1704) said, 'It is one thing to show a man that he is in error and another to put him in possession of the truth.'

Anthea and Sheila put us in possession of some very important truths vital to the continuance of our present attempts to achieve a renaissance for midwifery. This book could be the grit in the oyster and stimulate midwives to develop creative practice of the highest standard. Truly a pearl beyond price!

SARAH Roch 


\section{Acknowledgements}

The authors and publishers acknowledge with thanks permission from the following to reproduce copyright material: Open University Press, for Table 2.6, from D. Pilgrim and A. Rogers, A Sociology of Mental Health and Illness (1993); NPEU, Radcliffe Infirmary, Oxford, for Figure 2.7, from A. Macfarlane et al., Counting the Changes in Childbirth: Trends and Gaps in National Statistics (1995); Social Policy Association, for Table 5.1, from P. Selman, 'Teenage Motherhood Then and Now: comparison of the pattern and outcomes of teenage pregnancy in England and Wales in the 1960s and 1980s' (July 1994); The Independent, for Figure 6.2 (15 August 1995); Routledge, for Table 7.5, from R. Forrest and A. Murie, Selling the Welfare State: The Privatisation of Public Housing (1988). 


\section{List of abbreviations}

\begin{tabular}{|c|c|}
\hline AIMS & Association for the Improvement of Maternity Services \\
\hline ALRA & Abortion Law Reform Association \\
\hline ARM & Association of Radical Midwives \\
\hline BMA & British Medical Association \\
\hline CMB & Central Midwives Board \\
\hline DoH & Department of Health \\
\hline DOMINO & $\begin{array}{l}\text { Domicilary In and Out (i.e. care by midwife at home, hospital } \\
\text { admission for a brief period ( } 6 \mathrm{hrs} \text { ) only for the birth of baby, } \\
\text { then post natal care at home) }\end{array}$ \\
\hline EOC & Equal Opportunities Commission \\
\hline ESRC & Economic and Social Research Council \\
\hline GMC & General Medical Council \\
\hline GP & general practitioner \\
\hline HBA & households below average income \\
\hline LIF & low-income families \\
\hline MA & Maternity Allowances \\
\hline MIDIRS & Midwives Information and Resource Service \\
\hline $\mathrm{MoH}$ & Ministry of Health \\
\hline NCT & National Childbirth Trust \\
\hline OPCS & Office of Population Censuses and Surveys \\
\hline RCM & Royal College of Midwives \\
\hline RCN & Royal College of Nursing \\
\hline RCOG & Royal College of Obstetricians and Gynaecologists \\
\hline SMP & Statutory Maternity Pay \\
\hline SPUC & Society for the Protection of the Unborn Child \\
\hline UKCC & $\begin{array}{l}\text { United Kingdom Central Council for Nursing, Midwifery and } \\
\text { Health Visiting }\end{array}$ \\
\hline
\end{tabular}




\section{Introduction}

This book is essentially a guide to a general sociological perspective and to social policies which are significant both for midwives and for women and their families. It is not an introduction to either sociology or social policy but should be seen as a map which readers may use to guide them to further study, reading or thinking about some of the issues raised.

Midwives are a part of society not just as midwives but as women, wives, mothers, daughters, partners, tenants and consumers, and as such they are affected by social policies in their everyday lives. (Throughout this book midwives will be referred to as women as this is statistically and culturally the most accurate, men representing only 0.2 per cent of practising midwives [UKCC, 1994]). Likewise, the women for whom they care also play many roles, they are not just prospective mothers but may be workers and carers for others. Being pregnant is a very small but important segment of their lives: it is not the total of their lives.

In order to 'make sense' of the changing society in which they work, midwives will, we hope, find this book both interesting and challenging. It puts forward some ideas with which you may not agree. This is its purpose, to provoke analytical thought and discussion. It employs a 'womancentred' approach - that is, it focuses upon female experiences and upon the effects of policies on women. It cannot tell the student everything there is to know in these fields and there are bound to be omissions. The book is offered as a starting-point and as a guide to making sense of the social world in which midwives practise. Some students will be fascinated by the insights and will decide to develop their interest in the topics further. Some will find that understanding some of the concepts will add a new dimension to their midwifery care and encourage them to think and question more.

The danger implicit in any book like this is to assume that the authors are writing for undergraduate sociology and social policy students or at least are preparing mini-sociologists and mini-scholars of social policy. This is not the aim. The book is aimed at midwives and students of midwifery undertaking Diploma (level 2) and Degree (level 3) studies. Even midwives undertaking Masters degrees may find the text helpful. It aims to enhance the preparation of the midwife or inform the continuing education of the qualified midwife, so that she becomes more analytical, more thoughtful, more responsive, more understanding and more able to 
offer women appropriate, sympathetic, sensitive and realistic advice. To do this, today's midwife must be informed, well-educated and articulate. To rely on common sense is inadequate as common sense is ill-informed and based only on experience. It would be a great shame if the real value of sociology and social policy study for midwives was misunderstood. Midwives work in society. Society constructs the environment, manufactures the issues, sets the policy and deals with the fall out. Midwives give the care in that environment, to ignore the wider context of care and the issues therein is to diminish the care women receive.

This book is divided into two parts. Part I, containing the first five chapters, focuses on sociological theory and its application to midwifery practice. The contents of these chapters are intertwined and the links with midwifery practice are like society itself, neither simple nor straightforward. Many of the issues and concepts in this book do not exist in isolation but are interconnected. The questions and discussion points are linked to each chapter but information in other chapters will assist students in developing an understanding of the issues. At the end of Chapters 1, 2, 3, and 4 are case studies followed by questions and discussion points.

Part II, containing the remaining three chapters, is concerned with issues in social policy. Families, communities, women and midwives are considered and again the questions and discussion points draw on evidence in all chapters.

Chapter 1 gives an initial introduction into the academic discipline of sociology. It explains how sociology is a means of perceiving and theorising about the social world in which we live and suggests that when midwives study sociology and society in a more thoughtful and analytical way, they will begin to think more analytically about the care they give to women.

Chapter 2, on 'Social Divisions and Patterns of Inequality', is an especially important chapter and illustrates how sociologists attempt to explain divisions in society. It gives particular attention to social class, race, ethnicity, gender and age. This chapter offers definitions, suggests some causes of poverty, and considers some studies from the midwifery literature.

Chapter 3 offers sociological perspectives of the family and community and reveals that there is not just one model of the family but many different formations. The chapter explores not only ideologies of the family and community but also some of the myths and half-truths surrounding these concepts. The case studies in this chapter (as in the first two) are designed to help midwives to understand the different roles and responsibilities which women have in different households, so that they may offer appropriate care and advice to women and their partners. 
Chapter 4 is called 'The Social Aspects of Pregnancy and Childbirth'. It explores birth as a social and cultural event and the domination and medicalisation of birth in a patriarchal culture.

Chapter 5 explores the myths of motherhood and describes how it has been socially defined, limited and constructed. It explores post-natal illness and concludes that it is not simply a physical illness with a physical cause. Theories on bonding are considered and the role of fathers in birth and beyond.

Chapter 6 is the opening chapter of Part II and deals with issues in social policies. This chapter encourages the reader to be aware of policies on state benefits, marriage, divorce, children, etc., but more importantly to consider why social policy has been framed in the way it has. The reader will consider which theories underpin decisions in social policy and why gender roles have been institutionalised into health and welfare systems in Britain. This chapter includes questions and discussion points designed to encourage midwives to apply theory to aspects of clinical midwifery practice.

Chapter 7 is also about social policy and it describes how theories of the male-breadwinner role have shaped social policies. This chapter focuses on women and considers such issues as abortion, maternity benefits, and child care. Policies on housing and homelessness are considered and again the questions and discussion points are related to aspects of midwifery practice.

Chapter 8 explores the nature of professionalism and its significance and application for midwifery. It explores the social aspects of a profession and considers the influence of social class, gender and ethnicity in a professional group. The statutory control of midwifery is discussed as is the new control of the professions, 'managerialism'.

The case studies in this book are based on real-life situations. Such is the nature of midwifery practice that sometimes real life is more surprising and stranger than fiction. All the names are fictitious.

This is a book for students and midwives who are able to make use of relevant knowledge from a range of sources, who can explain, summarise, develop logical clear arguments, make links between areas of work, be independent, imaginative, creative and critical. Midwives who use this book should become more thoughtful, more analytical, more sceptical, more responsive and more able to generate new ways of providing midwifery care. This is the aim of the text. 